\title{
GENERATIONAL DIFFERENCES IN ACHIEVING WORK-LIFE BALANCE
}

\section{Aleksandra Janeska Iliev}

Department of Management, Ss. Cyril and Methodius University in Skopje, Faculty of Economics-Skopje, Republic of Macedonia

\section{Kiril Postolov}

Department of Management, Ss. Cyril and Methodius University in Skopje, Faculty of Economics-Skopje, Republic of Macedonia

\section{Marija Magdinceva Sopova}

University Goce Delcev - Stip, Faculty of Tourism and Business LogisticsGevgelija, Republic of Macedonia

OMESTE

JEL Category: J62

\begin{abstract}
Each generation is influenced by broad forces that create common value systems distinguishing them from people who grew up at different times. Reaching a balance between life and work is an intangible ideal considered to be a complete fairytale. But by making deliberate choices about which opportunities they'll pursue and which they'll decline, rather than simply reacting to emergencies, leaders can and do engage meaningfully with work, family, and community. The concept of work-life balance, as implied, consists of the management and balance of work responsibilities and non-work responsibilities. Professionals discover through hard experience that prospering is a matter of carefully combining work and home so as not to lose themselves, their loved ones, or their foothold on success. In that light the main goal of this paper is to find understanding for the main aspects of work-life balance and stressing the practical aspects of professionals in the struggle to face a satisfied professional and personal life, considering the attainment to a different generation. It has been widely discussed that individuals from different generations have been related to a different set of values which influences their image of what work-life balances mean. This paper aims at finding some ground bases for the analysis of, these different approaches, which could enable better organizational understanding of the needs of employees.
\end{abstract}

Keywords: Work Life, Professional life, Generation, Human Resource

Address of the corresponding author:

Kiril Postolov

麦=" kirilp@eccf.ukim.edu.mk

\section{INTRODUCTION}

Differences between generations are confounded with changes due to aging, experience, life stage, 
and career stage. (Cennamo, \& Gardner, 2008). The impending retirement of a large cohort of North American employees (Baby Boomers) has created a crisis in organizations as they strive to recruit and retain the younger generations, who purportedly hold significantly different values, attitudes, and expectations from the generations of workers who preceded them (Economist 2009) However, variations to work and the fact that each generation was introduced to work at differing points in time suggest that work value differences may exist between generations. The challenges related to professional orientation has made it particularly difficult to make decisions and choices related to family and pursuing a professional career path. Professionals take the challenging path of commitment and sacrifices in order to achieve outstanding results. However, engaging and commitment are just not enough nowadays, the fiercer the competitions are, the more specific career managing is needed. The main aim in this paper to present a relevant overview of the most important aspects influencing the actions towards achieving work-life balance. Work-life aspects have always been a concern of those interested in the quality of working life and its relation to broader quality of life (Guest, 2002). In general, the modern life imposes a certain misbalance related to professional and personal commitment which deteriorates the society on one hand and influences the results of organizations on the other.

At this point, it should be noted that there are many examples facing the issues, like those presented in this paper. Different authors have been discovering the layers of defining the work-life balance. The literature indicates different approaches for analyzing work-life balance. According to certain authors (Zedeck, \& Mosier, 1990) typically five models could be used for explaining the relationship between work and personal life. The following models could be distinguished: segmentation model, spillover model, compensation model, the instrumental model and conflict model. These models propose different relationships between work and personal life setting an emphasis on a professional or personal aspect. Organizations interested in implementing work-life balance policies are keen to track their own progress and, also, to compare their progress in relation to cross-organizational benchmarks (Bardoel, De Cieri, \& Mayson, 2008)

The empirical as the well theoretical discussion has been discussing the rewards and problems of balancing the demands of coexistence of employment and family life (Barnett, 1994) (Bielby, \& Bielby, 1989) (Brennan, \& Rosenzweig, 1990),(Higgins, et al., 1992). The understanding of work-life balance brings certain results both for the individual and for the organization, at the same time enables managing the optimization between those most important aspects of life. Managing work-life balance should result in a more content loyal employee on one side and better performance results for the organization where individuals are engaged on the other. There is certainly a strong implication that to understand work behavior in relation to work-life balance, we need to explore aspects of family life (Guest, 2002).

Work-life balance is defined as a state of equilibrium in which the demands of both a person's job and personal life are equal" (Word Spy, 2012). Work-life balance is founded on the idea that every person should have a complete life in which a sufficient amount of time is spent on personal interests and family interest. The organization is shaped by organizational, sociocultural, and individual-level factors (Bruening, \& Dixon, 2005). Mostly within our research, we have predominantly focused our research at an individual level factor. One of the main determinants influencing the attitudes towards certain behavior is strongly related to the person's values. Research has indicated influencing work-life balance concerns the values and attitudes of people in work engagements. This issue has been stimulated by writers advocating the arrival of Generation X (Tulgan, 1996), which has been specified by individuals who put a greater accent and prioritize seeking balance between work and personal life.

\section{THE GENERATION}

A generation can be defined as an "identifiable group that shares birth years, age location, and significant life events at critical developmental stages" (Kupperschmidt, 2000). The concept of generations dates back to the year 1952, to the work of Karl Mannheim (Mannheim, 1952). 
Research indicates that different generations exhibit different value priorities (Bogdanowicz, \& Bailey, 2002). The investigation of work characteristics is, therefore, an important area for research for diverge generational groups and results in different outcomes in investigating differences between the generational groups.

The generations show differences in how they value work (Cennamo, \& Gardner, 2008). The work style and belief systems of Generation $Y$ (employees aged from late teens the to mid-20s) is regarded as fundamentally different from any other group of young people in the last fifty years (O'Reilly, \& Vella-Zarb, 2000). A Price Waterhouse Coopers survey of 2500 University students in 11 countries found that $57 \%$ name "attaining a balance between personal life and career" as their primary career goal (O'Bannon, 2001). When discussing the notion of generation, like any other concept in the literature there can be found many different attempts. Basically, they all have one thing in common which is that under the term generation it is considered a group of people who are born, live and work in approximately the same historical timeframe. In addition, questions are raised, to determine the criteria which define the appropriate generation. Though the following factors are determined as more significant in defining the generation (Howe, \& Strauss, 2002):

- Year of birth;

- A sense of belonging;

- Common beliefs and behaviors;

- Sharing a common history.

The sense of belonging means creating a perception of belonging to a generation that has its beginnings in the puberty stage and ends at the stage of so-called young adulthood.

In terms of common beliefs and behaviors, the focus is pointed towards family and marriage, career, personal life, politics.

Sharing a common history involves joint participation in common and significant events that characterize the time in which they are present.

In terms of year of birth (which is usually considered as the fundamental criterion for determining the respective generation) different classifications could be pointed out. Belonging to an appropriate age is characterized by specific behaviors, as well as perceptions of reality.

Generation could be also considered as an identifiable group that shares birth years, age, location, and significant life events at critical developmental stages (Tolbize, 2008). Research indicated that authors have presented a wide number of definitions related to generations. Still, it could be stressed that members of one generation share experiences that influence their thoughts, values, behaviors, and reactions. Despite the fact that individuals bring their own specific personalities, some broad generalizations are possible about those born in approximately the same years. In this line considering one classification, the generations are divided into :

- A group of employees until 1950 ;

- Born between 1951 and 1960 ;

- Born in the period between 1961-1970 ;

- Born after 1971.

According to another classification (Martin, \& Tulgan, 2002), there are the following three groups (with their "synonyms") :

- Baby Boom generation (born between 1946 and 1964);

- Generation X (born between 1965 and 1977);

- Generation Y (born between 1978 and 2000 the so-called millennium generation).

Demarcations of generation boundaries are challenging. However, it has been considered that the two generational groups most analyzed in today's workforce are often called the Baby Boomers and Generation X. As for Boomers they are generally considered to be born between 1945 and the mid-1960s with the decline in birth rates that signaled the end of the Baby Boom. The generation now most active in the workforce corresponds with the rise in birth rates in the early 1980s when Baby Boomers began to have children and this has been referred to as the Baby Boom Echo, Generation Y, or Generation Next (Lyons, 2004).

\section{UNDERSTANDING OF THE GENERATION Y}

Generation $Y$ or Millennials refers to a generation born between the eighties and the start of the new millennium, having a different set of personality characteristics, values, behaviors, expectations, and perspectives. There are considered as the 
most educated, well traveled and technologically sophisticated generation in general. This generation has lived in a world of computers, the Internet, DVDs and cell phones. This group is considered to be less process or outcome focused. (Crampton et al., 2009) For generation $Y$ making a lot of money is less important instead their values are more oriented toward their contribution to society and their role as parents.

Generation $Y$ is similar to their Generation $X$ counterparts in that Generation $Y$ is independent, tech savvy, entrepreneurial, hardworking and thrives on flexibility (Martin, \& Tulgan, 2001). Generation $Y$ related to work engagement consider their job as a contract, not a calling. In general, it is considered that generations $X$ and $Y$ believe there is more to life than work-and this is especially true for Generation Y. Considering the different aspects of life Generation $Y$ works to live as opposed to living to work. The items below summarize the significant events that have occurred since 1980 (Crampton, \& Hodge, 2009).

- 1981: MTV

- 1984: AIDS

- 1986: Challenger Disaster

- 1995: The Oklahoma City bombing

- The 1990s: Clinton-Lewinsky scandal

- 1999: Columbine High School massacre

- 1980s-90s: Popularity of the Internet and ESPN

The first and main feature of members of this generation is that they are individuals who have never lived in a world without technology. That means that mobile phones, Internet, SMS, skype, facebook, twitter, etc., are an integral part of their lives. It is a generation that doesn't know how to calculate at heart, but does that using the help of computers and mobile phones; generation that does not know what it means to have a film in the photography camera; generation where the images of Fiat 750 and a blue Skoda $110 \mathrm{~L}$, are interesting, but unusual (yes, they will indicate as members of this generation, that their grandfather had this type of car). Somewhere in the 60s, 70 s or 80 s of the last century at a concert during some slow songs lighter were lit and used, now in the air are risen iPhones', tablets and so on.

The culture in which the members of this generation live, grow up and work, is characterized by high speed, uncertainty, turbulence, and major changes. Reliability, inertia, slowness, low turbulence were characteristics of the generations before (baby boom and generation $\mathrm{X}$ - as an example).

Generation $Y$ consists mainly, of the children of baby boomers, but their mindset, beliefs, values, and attitudes are far more different than those of their parents.

The members of Generation $Y$, have the following basic features:

- Access to modern IT and other modern technology;

- Participation in decision making;

- The existence of feedback;

- Teamwork ;

- Flexible and unbalanced fees ;

- Ready for equal negotiation.

But also these members (Generation $Y$ ), search for a proper career, balance between work and private life and independence. Finding the perfect career is more important for them than just finding work and job satisfaction is more important than the salary provided by an organization. Some of the main attributes of generation $Y$ are summarized and presented in Table 1.

It should be noted that some professionals as part of this generation have been interviewed. One of the main features of these individuals is that they require a balance between the professional and private life. Plus as individuals, they have been considered which despite everything are aiming to achieve that balance between professional and private life.

\section{Table 1. Attributes of generation $Y$}

1. They have an incredible amount of talent and believe that innovation is crucial to corporate growth.

2. Being wealthy is very important to them. They are fiercely ambitious and motivated by money, status and career advancement

3. They are not interested in political affairs.

4. They are closer to their parents as compared to previous generations.

5. They increasingly use and are very familiar with communication, media, and digital technologies.

6. Prefer communications through e-mail and text messaging over face to face interaction. They also prefer cyber training, webinars, and telecommuting. 
7. Excellent multitaskers. They can manage multiple streams of information across time zones and multitask with ease.

8. Prefers workplaces in an urbanized location with good public infrastructure.

9. They value flexibility, attractive salary package and flexible working hours and schedules. They also prefer additional vacation days to cash bonuses.

10. They are future-oriented, ready to contribute now, opportunity driven and prefer opportunity over job security.

11. They can be best described as self-confident and self-dependent, connected, optimistic, entrepreneurial and tech-savvy.

12. They aim high and do not think themselves limited by background. They think it is what you are that counts. They are believed to have high Internal Locus of Control.

13. They are self-expressive and unrestrained in self-expression. They write openly about themselves and friends online.

14. They are team players and like to work in teams and groups. They prefer a collaborative approach and interaction in the workplace.

15. They despise traditional command and control type of management still popular in much of today's workforce. They are not fond of the topdown leadership style that has until now dominated the professional world, preferring instead to collaborate in teams.

16. They attach great importance to diversity in our workplaces and are "tolerant" of different opinions, sexualities, ethnicities, and cultures than previous generations.

17. They view the office as an extension of their home life.

18. They are more literate and informed as compared to previous generations.

19. They crave instant feedback at work. They desire constant feedback from their superiors and seek knowledge from older generations in the workplace.

20. They want to be trusted and respected by their boss. Their ideal manager is a coach and mentor, or a friend, rather than someone who directs or examines and audits.

21. Meetings for them is pointless, redundant or huge time wasters.

22. They require continuing education, responsibility, flexibility, and personals goals from their employer.

Source: (Meier, J., Austin, S.F., \& Crocker, M.,

2010)

\section{ESTABLISHING BALANCE BETWEEN PROFESSIONAL LIFE AND PRIVATE LIFE}

Considering different generational characteristics, reported that Boomers: live to work; respect authority and hierarchy, and enjoy being in charge. Whereas in contrast, Xers: work to live; desire instant gratification; and - are self-reliant. (Gursoy, Maier, \& Chi, 2008). At the beginning work-life balance has been conceptualized in terms of work-family conflict (Carlson, et al., 2009). Changing the approach traditional family life has caused the rise of interest in these aspects of organizational life. The labor market and developments in family life such as the movement of women to the workforce and the increasing dual-earner households, work-life balance became an actual topic (Allen, et al., 2000).

Juggling competing demands is tiring if not stressful and brings lower productivity, sickness, and absenteeism, so work/life balance is an issue for all employees and all organizations (Swift, 2002). Work-life balance from the employee viewpoint concerns the dilemma of managing work obligations and personal/family responsibilities (Lockwood, 2003). Friedman and Greenhaus (2000) in their pioneering study included 800 business professionals indicating that work and family, are the dominant life roles for most employed women and men in contemporary society and at the same time they can either help or hurt each other (Friedman, \& Greenhaus, 2000). In real life, there is a high degree of duality. Organizations try to find ways to accommodate their employees in finding the right balance by offering successful work-life practices, while still aiming for high performance and economic success (White, et al., 2003). This duality is especially emphasized in ensuring a balance between professional and private life. It expresses in the existence of so-called "Parallel worlds", i.e. the division of existence into two independent parts. This approach requires, first, sorting people into categories. People who belong to our inner circle (family, friends, relatives) and people who belong to our outer circle (associates, customers, etc.).

People are distinguished accordingly in relation to how they set up their priorities in life, and ultimately value, success in their careers and lives. 
The values associated with the four life role priorities vary from group to group. There can't be a happy career if there is not a happy personal life and vice versa. An active role in ensuring the balance between professional and personal life provides great results for the organization where the individual is employed. Life role priority influences the decisions shaped by family structure, personal values, work experiences, and other factors. For setting priorities, in practice, there are several possible strategies, including:

- Finding the courage to refuse demands that are beyond achieving a balance between professional and private life;

- Requesting not to quit on ourselves when planning the balance between the professional and private life;

- Self-management (recognizing the paradigm considering the "limitations of time and the inability to store and return back" ) ;
- Time management (determining priorities, separating the important from the not important) ;

- Stress management;

- Change management

Additionally, the organization has to ensure the following:

- The support to ensure a balance of professional and private life;

- Determining the appropriate priorities for work;

- Identifying the signs of exhaustion and monotony:

- Seminars for balancing between professional and private life;

- Encourage programs for recreation and relaxation;

Table 2. Generational difference in the approach toward work-life balance

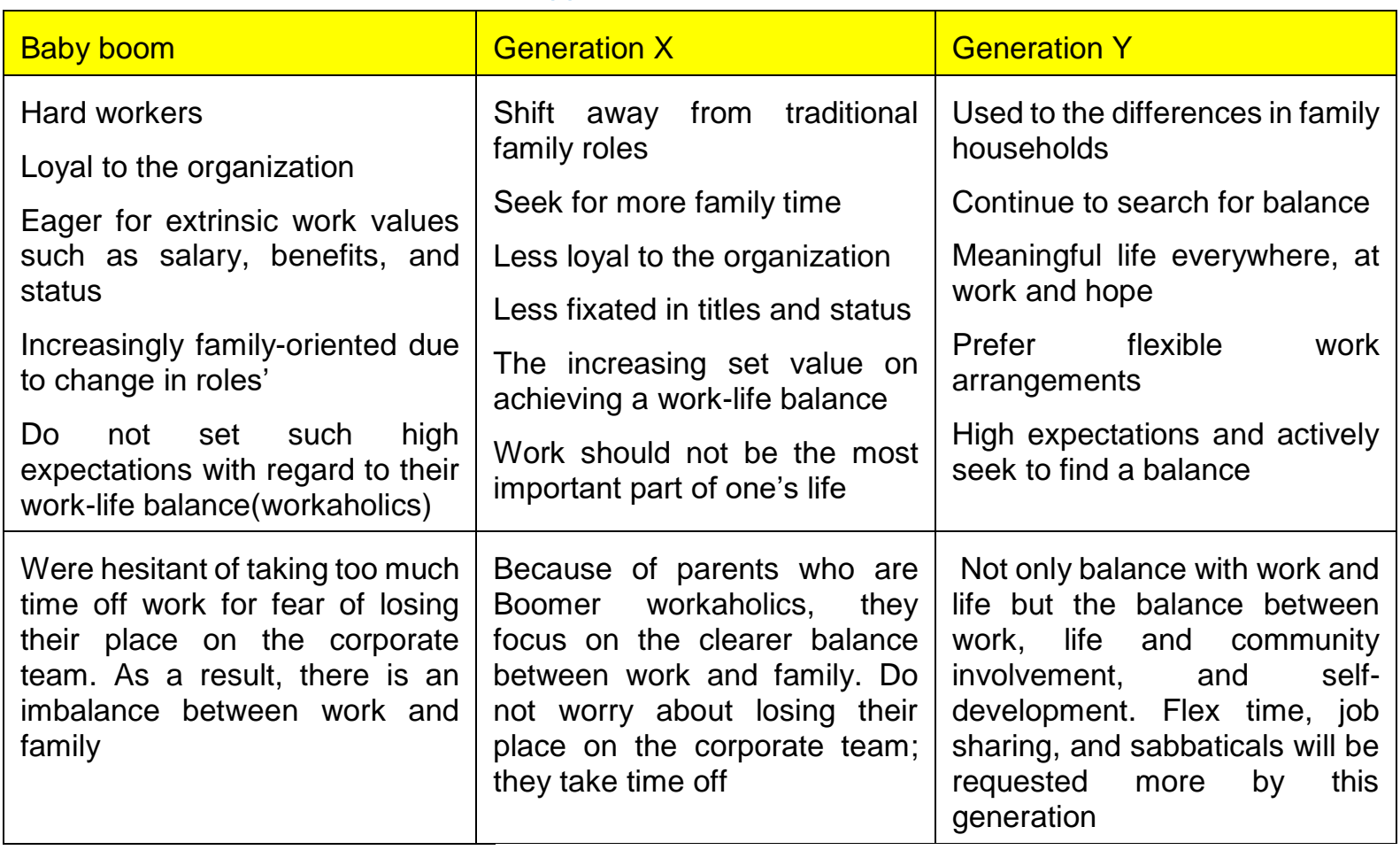

Adapted according to Van de Ven, A. (2011) and Crampton, S.M. \& Hodge, J.W. (2007).

Researchers have been interested in how different generations approach this issue of work-life balance. It has been widely discussed that there have been a clear shift and so how generations value and approach their work is an important question nowadays (Levenson, 2010). Since we are more and more witnessing a multigenerational working environment where many different generations meet, in order to facilitate their coexistence, the organization needs to be aware of their approach towards this issue. Hence in table 2 below are presented some of the main facets of different most active generations within the working labor force. 


\section{CONCLUSION}

Employees are of no use to the organization if stressed and torn between family and profession. The key to making any organization successful lies in the satisfaction, commitment and deliberate involvement of the employees. Considering the different aspects of work-life balance the decision process is mainly related to the individuals basic set of values. It has been discussed widely that the attainment to specific generations predefines certain behavior. Therefore, in our observation the fact that the individual belonging to the so-called Y-generation or Millenials gives an implication that these person puts great emphasis on personal and professional balance, devoting high ranking in their priorities on personal issues. Work-life balance is a tool that has been adopted by the most successful organizations so both sides the individual and the organization itself should make an effort in order to achieve the best result. Hence work-life balance initiatives are the win-win situational tools for the employers and the employees as the organization's goals are accomplished and fulfilled successfully along with the personal needs of the employees. Based on the issues mentioned above it becomes clear that work-life balance is not only an individual issue but also an organizational issue. Putting this into perspective provides additional information valuable for both the individual and the organization. It sets the ground lines for handling certain aspects of organizational life which are important for using human resources in the most efficient manner, minimizing fluctuations and absenteeism.

\section{WORKS CITED}

Allen, T.D., Herst, D.E., Burck, C.S., \& Sutton, M. (2000). Consequences associated with work to family conflict: A review and agenda for future research. Journal of Occupational Health Psychology, (5), 278-30

Bardoel, A., De Cieri, H., \& Mayson, S. (2008). Bridging the research-practice gap: Developing a measurement framework for work-life initiatives. Journal of Management and Organization, 14(3), 239-258

Barnett, R.C. (1994), Home-to-work spillover revisited: A study of full-time employed women in dualearner couples. Journal of Marriage and Family, 56, 647-656.

Bielby, W. T., \& Bielby, D. D. (1989). Family ties: Balancing commitments to work and family in dualearner households. American Sociological Review, 54, 776-789.

Bogdanowicz, M. S., \& Bailey, E. K. (2002). The Value of Knowledge and the Values of the new Knowledge Worker: Generation X in the New Economy. Journal of European Industrial Training, 26(2), 125 - 129.

Brennan, E. M., \& Rosenzweig, J. M. (1990). Women and work: Toward a new developmental model. Families in Society. The Journal of Contemporary Human Services, 71, 524-533.

Bruening, J.E, \& Dixon M.A. (2008). Work-Family Negotiations Within a Life Course Perspective: Insights on the Gendered Experiences of NCAA Division I Head Coaching Mothers. Springer Science Sex Roles, 58, 10-23

Carlson, D.S., Grzywacz, J.G., \& Zivnuska, S., (2009), Is work-family balance more than conflict and enrichment?. Human relations, 62(10), pp.1459-1486.

Cennamo, L., \& Gardner, D. (2008). Generational differences in work values, outcomes, and personorganization- values fit. Journal of Managerial Psychology, 23(8), 891-906

Crampton, S., \& Hodge, J. H. (2009). Generation Y: Unchartered Territory, Journal of Business \& Economics Research, 7(4), 1-6.

Crampton, S.M. \& Hodge, J.W. (2007). Generations in the workplace: Understanding age diversity. Cambridge: The Business Review, 9(1), 16-23. 
Economist. (2009, October 29). Public-service careers: A tough search for talent. Retrieved from http://www.economist.com/world/international/displaystory.cfm?story_id=14753826

Friedman, S.D., \& Greenhaus, J.H. (2000). Work and Family--Allies or Enemies?: What Happens When Business Professionals Confront Life Choices. Oxford University Press, USA.

Guest, D. (2002). Perspectives on the Study of Work-life Balance. Social Science Information, 41(2), 255-279,

Gursoy, D., Maier, T., \& Chi, C.G. (2008). Generational differences: an examination of work values and generation gaps in the hospitality workforce. International Journal of Hospitality Management, 27(3), 448-58.

Higgins, C. A., Duxbury, L. E., \& Irving, R. H. (1992). Work-family conflict in the dual-career family. Organizational Behavior and Human Decision Processes, 51, 51-75.

Howe, N., \& Strauss, B.(2000). Millennials Rising: The Next Great Generation, Random House, Toronto.

Kupperschmidt, B.R. (2000). Multigenerational employees: strategies for effective management. The Health Care Manager, 19(1), 65-76.

Levenson, A.R. (2010). Millennials and the world of work: An economist's perspective. J Bus Psychol, 25(2), 257-264.

Lockwood, N.R., (2003), Work/Life Balance: Challenges and Solutions. SHRM Research, USA.

Lyons, S. (2004). An exploration of generational values in life and at work. Dissertation Abstracts International, 3462A (UMI No. AATNQ94206).

Mannheim, K. (1952). Essays on the sociology of knowledge. London, UK: Routledge, 276-322

Martin, C. A., \& Tulgan, B. (2001). Managing Generation Y. Amherst. MA: HRD Press.

Martin, C.A., \& Tulgan, B., 2002. Managing the generation mix: From collision to collaboration. Human Resource Development.

Meier, J., Austin, S.F., \& Crocker, M. (2010). Generation Y in the Workforce: Managerial Challenges. The Journal of Human Resource and Adult Learning, 6(1), p. 68

O'Bannon, G. (2001). Managing Our Future: The Generation X Factor. Public Personnel Management, 30(1), 95-109,

O'Reilly, B., \& Vella-Zarb, K. (2000). Meet the Future. In R. Luhman (Ed.), The Sociological Outlook: A Text with Readings (7th Ed. ed.). San Diego: Collegiate Publishing Group.

Swift, L. (2002). Work-life balance important in relief world, too. Reuters AlertNet. Retrieved from http://www .alertnet.org/thefacts/reliefsources

Tulgan, B. (1996). Managing Generation X: How to Bring out the Best in Young Talent. Oxford: Capstone

Van de Ven, A., (2011), How generations balance work and private life., University of Tilburg,

White, M., Hill, S., McGovern, P, Mills, C. \& Smeaton, D. (2003). "High-performance management practices, working hours and work-life balance", British Journal of Industrial Relations, Vol.41, pp.175-195.

Word Spy. (2012, March 12). Work-life balance. Retrieved from http://www.wordspy.com/words/work lifebalance.asp

Yarnall, J. (1998), Line managers as careers developers: rhetoric or reality. Personnel Review, 27(5), 378-395. https://doi.org/10.1108/00483489810230325.

Zedeck, S., \& Mosier, K. (1990). Work in the family and employing organization. American Psychologist, 45(2), 240-251. 
Received for publication: 16.12 .2017

Revision received: $\quad 11.08 .2018$

Accepted for publication: 27.12.2018

\section{How to cite this article?}

Style - APA Sixth Edition:

Iliev, A. J., Postolov, K., \& Sopova, M. M. (2019, January 15). Generational Differences in Achieving Work-Life Balance. (Z. Čekerevac, Ed.) MEST Journal, 7(1), 7-15. doi:10.12709/mest.07.07.01.02

Style - Chicago Sixteenth Edition:

Iliev, Aleksandra Janeska, Kiril Postolov, and Marija Magdinceva Sopova. 2019. "Generational Differences in Achieving Work-Life Balance." Edited by Zoran Čekerevac. MEST Journal (MESTE) 7 (1): 7-15. doi:10.12709/mest.07.07.01.02.

Style - GOST Name Sort:

Iliev Aleksandra Janeska, Postolov Kiril and Sopova Marija Magdinceva Generational Differences in Achieving Work-Life Balance [Journal] // MEST Journal / ed. Čekerevac Zoran. - Belgrade - Toronto : MESTE, January 15, 2019. - 1 : Vol. 7. - pp. 7-15.

Style - Harvard Anglia:

Iliev, A. J., Postolov, K. \& Sopova, M. M., 2019. Generational Differences in Achieving Work-Life Balance. MEST Journal, 15 January, 7(1), pp. 7-15.

Style - ISO 690 Numerical Reference:

Generational Differences in Achieving Work-Life Balance. Iliev, Aleksandra Janeska, Postolov, Kiril and Sopova, Marija Magdinceva. [ed.] Zoran Čekerevac. 1, Belgrade - Toronto : MESTE, January 15, 2019, MEST Journal, Vol. 7, pp. 7-15. 